\title{
METHODOLOGICAL DIVERSITY OF RESEARCH ON LEADERS AND INTERNATIONAL CONFLICT: A REVIEW
}

\author{
Öner AKGÜL ${ }^{*}$
}

Makale Geliş Tarihi-Received: 10.07.2019

\section{ABSTRACT}

Why leaders decide to go to war or when they decide to make peace? It can be one of the most common questions of classical thinkers and current scholars of international relations. The basic idea behind this question is to find out a solution to the war phenomenon. However, the other question is how we understand and explain the behaviors of leaders and their inner circles? Do rationality, strategic calculations or only cognitive variables sufficiently explain the violent behaviors? This research discusses how different methodologies can contribute to theorizing or understand the international conflict behaviors of leaders. In this context, on a qualitative basis, psychobiography, psychohistory, leadership trait analysis, integrative complexity method are explained along with the quantitative findings and theories of leaders and international conflict. The methodological diversity provides both deep insights about specific leaders' war decisions and general theories that can contribute to the scientific study of international conflict. I argue that the field is open to any new methodology.

Keywords: Leaders, International Conflict, Methodology, Personality, Data.

Jel Codes: D72, D74, F51, H56

Asst. Prof., Kırşehir Ahi Evran University, Faculty of Economics and Administrative Sciences, Department of International Relations, Kırşehir/Türkiye.oakgul@ahievran.edu.tr ORCID: https://orcid.org/0000-00022245-5124. 
Öner AKGÜL

\section{LIDERLER VE ULUSLARARASI ÇATIŞMA ARAŞTIRMALARINDA METODOLOJİK ÇEŞİTLİLIKK: BİR GÖZDEN GEÇİRME}

\section{ÖZ}

Liderler neden savaşa karar verir ya da ne zaman barışta karar kılarlar? Bu soru, klasik düşünürlerden günümüzün çağdaş araştırmacılarnna kadar en ortak sorunsallarından biri olarak karşımıza çıkar. Bu sorunun altında yatan en temel etken, esasen savaş olgusuna bir çözüm bulabilme istencidir. Ancak bir diğer önemli sorunsal, liderler ve onlarn iç çemberlerinin davranışların nasıl anlayacağımız ve açıklayacağımızdır. Rasyonalite, stratejik hesaplamalar ya da sadece bilişsel süreçler yeterli bir biçimde çatışma davranışın açıklayabilir mi? Bu çalışma liderlerin çatışma davranı̧̧larımı anlamak ve açıklamak için kaç farklı yöntemin uygulanabileceğgini, uluslararası ilişkiler teorisine katkıların tartışmaktadır. Bu bağlamda, nitel metodoloji bağlamında psikobiyografi, liderlik karakter tahlili, entegre karmaşıklı yöntemleri açıklanırken, bununla birlikte ampirik literatüre dayal nicel verilere dayah liderlik çalışmalar ile historiometrik yöntemler hakkında bilgi verilmektedir. Bu metodolojik çeşitlilik, hem belirli liderlerin savaş kararların nasıl aldıkları hakkında detaylı bilgiler edinilmesini sağlamakta ve aynı zamanda liderlerin savaş durumundaki genel davranış kalıplarını açılayan bilimsel çalışmaları da içermektedir. Alan, yeni bir çok metodolojiye açıktır.

Anahtar Kelimeler: Liderler, Uluslararası Çatışma, Metodoloji, Kişilik, Veri.

Jel Codes: D72, D74, F51, H56 


\section{INTRODUCTION}

The humanity first organized under a hierarchical structure for itself and named it as the state. Then pushed their states to compete with each other to gain territory, policy, regime or any other issue. The war phenomenon is as old as the emergence of the state. The increasing number of states created the bilateral relations that paved the way for interaction opportunity because of their territorial approximation. The cumulative dyadic interaction of states generated the international system structure. A group of imperial relations among a few empires ended up with the transformation of the international system and the emergence of nation-states. The increasing number of states generated new interaction opportunities for the new actors of the international system. Each born and die of the states caused a war that changed the dyadic, regional and even systemic dynamics. The process throughout the centuries shows us the probability of war is always alive, the distribution of capabilities will always change, and there will always be a challenger and target even in a dyadic relationship or in a systemic hierarchy. From this point, it can be argued that typologically there had been small or big wars, in other words, dyadic or systemic wars that resulted in high or low casualties. Besides the results of wars on a system, dyad, and state levels, all those fighting activities outbreak by a decision of a decision-maker who has rational calculations on what they expected or the result of their emotions, beliefs, perceptions or images that lead them to fight.

The efforts on the scientific study of peace and the endeavors on the understanding of the causes of war enabled us to perceive the origins of interstate violence, which is also a long-term matter of international political theory. Even different scholars on international relations found various findings on the explanation of the war; they principally have gone a long way towards understanding the causes of war ultimately. Besides this, the scholars distinguished themselves by taking different names such as war studies, peace research, peace science, conflict research, conflictology, polemology, irenology, paxology, etc. It can be argued that it was the natural result of methodological debate even if almost all of them were trying to perceive the causes of war. The debates on the causes of war can be traced back to experimental vs. non-experimental, case study or statistical analysis, rational modeling or cognitive explanation. How can political data be created and which resources be used to make 
peace research? How can the findings of the field be unified in a single theory or do we generate various theories on international conflict?

Despite the fact that the frequency of interstate war is on a declining trend, no one can promise today that an interstate war might not be outbreak suddenly, such as the period before World War I. History and the theories of international relations have revealed that the rising challengers and declining states may drag the system, states, and societies into a war. Due to this, the scholars are still progressing today to perceive the mechanisms that causing war and updating their formerly used methods through the usage of new approaches both qualitative, quantitative and mixed. In this direction, the literature on the causes of war produced various findings at the systemic, dyadic, state and societal levels. However, the effect of individual leaders remained qualitative and almost presumptive apart from a few exceptional studies. Particular rational models perhaps can assess it; however, those models include only rational behaviors rather than cognitive ones. In that sense, quantification of decisionmakers' lives, their characteristics and psychological orientations might provide answers and complete the war puzzle within a methodological consistency.

This study has three different aims. The first is to explain how many different research methods can apply to the question of leaders and international conflict. The second is to give a brief explanation of the theorizing of international conflict. The last aim is to make a discussion on which method can contribute theorizing process on leaders' behaviors pre and during international conflict. Instead of analyzing why leaders fight, it is explained in the article how many different methodologies are used on the individual level of analysis of conflict.

\section{A BRIEF LITERATURE REVIEW ON THE ROLE OF LEADERS AND WAR}

Together with the rise of neo-realist and liberal institutionalist theories in international relations, the role of individuals, leaders, were ignored due to those theories explained the international politics as a mechanism which is effective on the state behaviors. State-centric theories on war and peace ignored the leaders' critical roles during the 
international crises. However, various researchers insisted to prove that the leaders are significantly effective in decisions for war as well as other levels. After the end of the Cold War, neo-classical realism emphasized that domestic dynamics and decision-makers are remarkably effective in international relations. (Lobell et. al., 2009; Rose, 1998). Besides, the foreign policy analysis (FPA) scholars provided significant findings on the leader behaviors in interstate relations.

As Blainey noted that the decision-makers strongly be influenced by various factors, such as military capability and its effect on the war field, third party behaviors, perception on the social integrity of both adversary and his/her land, their backgrounds on war realities and sufferings, nationalism and ideologies of sides, economic capacity to maintain war and lastly the personality and experiences of decisionmakers. (Blainey, 1988: 293). These factors remind us to consider on dyadic and state-level variables together with the individual-level analysis. From this point of view, I shall argue that the perceptions, personal experiences and personality traits as important as the other variables that caused the war. In that sense, the individual level focuses on the decision-making process of leaders regarding how and why leaders decide to go to war.

The questions arising from the individual level highlight some keywords in our minds. Human nature, rationality, game theory, expected utility, misperceptions, personality traits; leader psychology, cognitive processes, beliefs, images, fears, emotions, and expected utility are the keywords that revolve around the individual level of analysis. However, as it was emphasized above, these issues about human decisions include both rational and cognitive points. Due to this, each of them requires different methodologies to find out how they are effective on war behaviors of leaders or how statesmen think. In that sense, multidisciplinary international relations research may provide an answer to our questions.

The classics of political philosophy firstly focused on human nature as the basic reason for war. The nature-nurture debate was the first divergence on the role of human understanding toward politics and war. Along with this, the human proclivities on violent behavior became a multidisciplinary question that benefited political science and international relations. Anthropology, archeology, history, 
biology, and neurology highly contributed the human aggressiveness. As Sevilla Statement of 1986 on violence emphasized that the violence is not the instinctive behavior of humans, but it was invented as assessed by Mead. (Mead, 2000). Understanding the mindset of individuals more complex due to their intangible nature. Its reflections can be found in the research on why leaders resort to war.

The individual level of analyses in international relations highlighted various aspects of decision-making and war. These aspects can be found within various research as both rational and non-rational. The quantitative scholars on decision making were largely based on

Decision-making is a process that includes exogenous and endogenous variables. Exogenously, the domestic and international environment put pressure or create an opportunity for decisionmakers' mindset during an international crisis. Endogenous variables can be regarded as more about personality and underlie in the past of decision-makers, such as childhood experiences, enemy images, traits, etc... Considering both, one should argue that the international relations scholars are more interested in the exogenous variables that affected the behaviors and decisions of leaders while political psychologists paid more attention to endogenous variables. However, together with the rise of political psychology, scholars from both fields integrated their findings to find out how leaders influence the destiny of an international crisis. In that sense, we have various findings on leaders and international conflict.

The perceptions and misperceptions of the adversary's intentions or behaviors can be regarded as one of the most common fields of theorizing leaders and international conflict. (Jervis, 1976, 1993, 2017; Levy, 1987, 1983). Understanding the leader's or the decision circle's perception towards an international crisis provides important insights for theorizing the behaviors of leaders and international conflicts. In that sense, the cognitive processing of an individual is a complementary part of understanding state behavior. The decisionmaking process is required to analyze how their cognitive processing influences the outcome of international crises and conflicts. 
Integrative complexity theory reflects the information processing capability of an individual which applied by the political psychology scholars to the political leaders during international crises. (Suedfeld, et. al, 1977). Scoring the integrative complexity was an important attempt to explain the international crisis and war behavior of states. (Guttieri, et. al, 1995; Suedfeld, Jhangiani, 2009; Suedfeld, Tetlock, 1977; Suedfeld et al., 1977; Walker, Watson, 1994; Winter, 2007). Perceptions/misperceptions and cognitive processing of political leaders are notably effective on the leader's decisions during international conflict and war. Such as perception, the scholars paid more attention to particular traits such as risk-taking behavior. The risk is conceptually important to understand the behaviors of leaders during the conflict. Conflict management, strategic behavior, gain-loss calculations require studying risk in international relations. In that sense, the scholarly findings on risk propensity, loss aversion contributed theorizing the leaders and international conflict. (Levy, 1992a, 1992b, 1996, 1997; McDermott, 2001, 2004; Mercer, 2005; Shafir, 1992). Besides, the diversionary theory of war literature is important to understand when leaders take extreme risks to initiate an international conflict. (Fordham, 2005; Miller, 1999; Tir, 2010).

\subsection{From 'Opportunity' to 'Willingness'}

Particularly the quantitative scholars on the causes of war produced substantial knowledge on why wars happen from systemic to dyadic levels. However, as it was emphasized before the leaders are considerably complex units of analysis. In that sense, integrating those complex units into the structural mechanisms of war requires a framework. Concisely, this approach to the scientific study of war leads us to explain a pre-theoretical framework. To that extent, the basic question here is how to situate the role of individuals in the frame of war possibilities.

In his oft-cited research, Starr designed the well-known framework on the scientific study of war called as opportunity and willingness. (Siverson, Starr, 1990, 1991; Starr, 1978) Accordingly, in the context of interstate wars, opportunity can be explained as the possibility of interaction between the political units, states. Willingness is a concept that more about foreign policy decisions based on the decisionmakers' motives or images in the context of their goals. This framework focused on the decision-making mechanism to lead them 


\section{Öner AKGÜL}

to decide a war. In that sense, willingness is more about the motivations and images of decision-makers while the opportunity is more about the interaction. (Starr, 1978). Before making an explanation on the research methodologies on leader' war behaviors, firstly clarifying the logic of war research may provide integrity to situate the decision-makers' willingness into the opportunity.

The historical observations on the prewar processes, research on single war cases, empirical and non-empirical studies demonstrate that the war is a multi-causal phenomenon that has both domestic and international dynamics. (Vasquez, 2009) In that sense, the explanation

34 of the causes of wars requires multidimensional analysis by dividing those dynamics and studying separately. The level of analysis framework emerged to systematize to explain the issues such as war. (Singer, 1961) Accordingly, which level of analysis is more important on the examination of the causes of wars became a question among the scholars? In structural realist tradition, system and state level of analysis utilized for studying international relations. (Waltz, 2001). However, considering a war entails focusing on the interaction of actors as well as the other levels. The interaction among a pair of states named as a dyadic level by the peace science tradition highlighted the importance of bilateral conflict possibilities give the best opportunity to understand why and how wars occur. (Bremer, 1992) As Vasquez underlined that, the most important level on the understanding war is the dyadic level that provides the examination of what the states actually do to each other. (Vasquez, 1998). In that sense, Vasquez's steps to war theory and Bremer's dangerous dyads concepts significantly contributed to the peace theory. (Bremer, 1992; Senese, Vasquez, 2005). They provide a set of conflict possibilities which can be understood as the opportunity for war. From this point of view, as Vasquez and Senese empirically proved that territorial disputes are the key aspect to understand the causes of war, they also highlighted particular issues that are more sensitive to international conflicts, such as the territory. It can be maintained that the power politics between the states together with the territorial disputes increase the risk of war. Besides, the alliances catalyze the counter alliances that result with the military build-ups. Recurrent crises are also effective to understand how dyads drag into the war. (Senese, Vasquez, 2005: 607-608). In that sense, territory and proximity gain importance on the explanation of war opportunity. 


\section{Methodological Diversity of Research on Leaders and International Conflict: a Review}

As an analogy, systemic and state levels are important to understand how the opportunities emerge for the possibilities of events, behaviors or leaders. Together with the rise of neoclassical realism, foreign policy analysis or political psychology, it can be argued that decisionmakers of those dyads deserve special attention to understand how they played critical roles by changing the output. If the all decision for war firstly outbreaks within a dyad, it means that particular decisionmakers play a critical role in the destiny of international crises. As Blainey reminded us; there can be no war unless at least two nations prefer war to peace. (Blainey, 1988). Leaders rather than institutional mechanisms made the preferences on war or peace. Horowitz and others emphasized that prior experiences are also effective to decide to go to war. (Horowitz et. al, 2015). Accordingly, it can be argued that the personal attributes catalyzing the behaviors of leaders and the conditions that make it easier to outbreak of a war for dyads should be assessed together during research on the war. From this point of view, peace science tradition or empirical theory of international relations provides a useful framework for understanding the opportunity while the willingness underlies in the leader' and their inner circles' personality and cognitions.

In empirical methods of international relations, there have been various debates on how the role of individuals should be included in the explanation of pre-war processes. By referring to Vasquez, hardliners are important to understand the decision for war, however, personality traits can change over time. (Vasquez, 2009: 219). In contrary to this political psychology highly focuses on the personality traits, characteristics and other endogenous dimensions of political leaders. (Hermann, 1980, 2005; Winter et. al, 1991). In that sense, it can be argued that the schools on conflict theory can be in a distinctive way that it was clarified by Horowitz and Fuhrmann. (Horowitz, Fuhrmann, 2018)

Horowitz and Fuhrmann present a classification on the role of individuals on war decisions. According to them, two distinct schools are important to understand the individual level of analysis and decisions for war. The first school, institutional leadership school focuses on the effects of the domestic and international environment that is the basic determinant of the leader's behaviors on war and peace. (Horowitz, Fuhrmann, 2018: 2073). If it is commentated within the scope of Starr's pre-theoretical framework, the members of this school 
analyze how the 'willingness' emerge within the framework of opportunity. The second one, named as leader attribute school, paid more attention to leaders' personal and individual beliefs, images, experiences that shaped the decisions for war or peace. (Horowitz, Fuhrmann, 2018). It can be seen that both schools produced data and knowledge on why leaders fight. However, those researches instrumentalized quantitative data and quantification of qualitative data. Particular researchers assert that qualitative research on leaders is also important to understand how specific or deviant cases and depth analyses can contribute to the field. It means that particular qualitative research results can be effective in quantitative theorizing.

By referring to Parry et. al., case studies can provide unexpected ideas during research and an effective understanding of particular processes. They assert that qualitative studies on leadership provide an opportunity to generate empirically supported ideas and theories and deep roots of leadership. (Parry, et. al, 2014). By confirming their assessments, my argument is the quantitative and qualitative schools of leadership cannot be rival, but complementary. In that sense, clarifying how many different types of leadership research can be made on international conflict can be utilized to present a framework for researchers.

\section{THE METHODOLOGICAL DIVERSITY TO EXPLAIN WHY LEADERS FIGHT}

The leadership analysis benefits from different sciences and disciplines. Besides this, leadership studies produced a great amount of research that the researchers from other disciplines are today contributing to this subfield. Besides political scientists, it is obvious that historians, sociologists, psychologists, and even business scholars focus on this field. In that sense, these scholars empirically utilized different methodologies to analyze the leaders at a distance. Methodologically the leadership analysis consists of different ways in accordance with the aim.

By considering the five title typology that emphasized by Parry et al (2014) in leadership studies, it can be discussed in this review how many different types of analyses can be made methodologically to the field of leaders and international conflict for IR scholars. 
(I) Specifically for empirical scholars, quantitative analysis of quantitative data can be regarded as more convenient comparing to the other methods, particularly political science and international relations. Also, it can be observed from the research of political scientists, historians and economists use this method frequently. It denotes that these types of research include to collect quantitative data of leaders such as birth and death dates, the dates of taking power, categorical variables on how leaders entry and exit in power, vocational experiences, their post-tenure fate, etc. (Chiozza, Goemans, 2004, 2011; Debs, Goemans, 2010; Goemans, 2003). The variables on the leader's experiences and effects on international conflict can also be assessed within this category. (Horowitz et. al, 2005; Horowitz, Stam, 2014; Horowitz et al. 2015). Those scholars highly contributed to theorizing the international conflict behaviors of leaders.

(II) quantitative analysis of qualitative data that includes textual analysis, research focusing on content. This methodology comes from an understanding of which quantification of psychological or personal attributes of political leaders. It can be argued here that the most common research methodology among the international conflict scholars is Leadership Trait Analysis (LTA) uses content analytical techniques and developed for exploring the linkage between the personality and foreign policy behaviors. (Hermann, 1980, 2003). Besides, historiometric methods are also significant to classify outstanding leaders. (Simonton, 1990, Ligon, 2008).

(III) The other method is more reflectivist and post-modernist way of understanding leadership behavior. In other words, qualitative analysis of quantitative data is used for ethno-statistics or discourse analysis on the purpose of deconstruction of quantitative leadership analysis. These types of research highly focused on the analyses of discourse that can contribute our understanding of the leaders' behavior during crises.

(IV) Perhaps the most common field in international relations can be regarded as qualitative research including case studies, phenomenology, ethnography, narrative research and grounded theory, Parry et. all define them methodologically as qualitative analysis of qualitative data which includes both post-positivist and interpretive ways. In other words, the deep analyses on selected leaders help to explain the cause of specific war case. In that sense, the 
biographies, psychobiographies, psychohistories, memories of decision-makers can be the best examples of understanding the causes of particular wars. (Falk, 1985)

(V) And the last one is mixed methods that can be regarded as quite new in leadership and conflict studies.

These five attempts are not special for political science and international relations, but they were used in various analysis of war and peace. The first one is more traditional for political science due to its quantitative nature and is used for war studies. The other ones are more complex and include substantial qualitative data. These methods presented new theories, methods or models for the leadership researchers. However, the basic aim behind the research on leaders is theorizing of their behaviors or perceptions. In that sense, the problem of the number of observations gains importance.

The basic question is how many different types of leadership research can be made on international conflict. In order to find out this question, a kind of distinction has to be made for creating a research framework. To make a comprehensive typology on leaders and war, I argue that five types of research can be made on leaders and wars including qualitative, quantitative or mixed.

1. Understanding a specific leader's decision to initiate or terminate a particular war. Single leader/single case. Qualitative, historical and biographical research including psychobiography.

2. Understanding a specific leader's decision for all wars in his career. Single leader/Small N case. Qualitative, historical and biographical research including psychobiography.

3. Understanding a specific leader's personality characteristics and decisions for war. Qualitative-Quantitative, Single/multiple leaders, Small and Large N Cases. LTA, Cognitive complexity methods.

4. Understanding leaders' decisions to go to war in one country. Multiple leaders/Small $\mathrm{N}$ or large $\mathrm{N}$ case. Comparative case studies gain importance in this kind of research. QualitativeQuantitative 
Methodological Diversity of Research on Leaders and International Conflict: a Review

5. Explanation of leaders' war decisions theoretically. Multiple leaders/large N Cases. Quantitative methods are appropriate. Large N Qualitative studies are also significant for theorizing.

The IR scholars in the world paid attention to empirical or nonempirical methods to reveal their findings. Due to this, some scholars are qualitative when compared to quantitative scholars. However, it can be argued here that both schools of IR contributed both explanation and understanding of war phenomenon. In that sense, these five attempts also represent various research traditions in the world.

\section{THE PROBLEM OF "N" AND THEORY CONSTRUCTION FOR LEADERS AND INTERNATIONAL CONFLICT}

The theorizing is an important aspect of providing prediction and framework for political scientists. The basic question arising from those data and analysis methods is which of them may contribute much more to theory construction on the causes of leaders' war decisions. This question directs us to answer the intention of the researcher. The aim of making research is either understanding or explanation. In that sense, how many cases enough to understand or to explain the leaders' cognitions and behaviors toward wars. If the researcher tries to understand the causes of a specific war, the single or small $\mathrm{n}$ case studies can be applied to the hypotheses. It may also help to figure out the unexplained dimension or anomalies that do not conform to the existing theories. If the research tries to explain a behavior about leaders and international conflict, then the large $n$ studies would be more utilized for theorizing.

The number of the case determines the exploratory and explanatory power of the theory. In that sense, I made a distinction between the numbers of cases and theoretical contributions. As a starting point, the selection of cases can be explained in threefold: single $n$, small $n$, and large $\mathrm{n}$ case studies. A single $\mathrm{n}$ case study in leaders and international conflict includes the analysis of a specific leader's cognitions on the decision making process and mindset to go to war. This type of research implemented by qualitative analysis of qualitative data. Single $\mathrm{n}$ case studies include psychobiographical data of leaders, private life information such as fears, emotions, bias, childhood 
experiences, leadership traits, etc... Those studies have great advantages in understanding the deep roots of particular wars. However, the theorizing capability of single $\mathrm{n}$ research is very limited with few exceptions as it was mentioned above. In that sense, the single case studies are more about to understand a specific cause of war instead of theorizing the causes of wars. Small N Case studies have comparative advantages on theorizing because of seeking the same variables from various political leaders' war decisions. The large $\mathrm{N}$ case studies are more appropriate for theorizing and most hypotheses on leaders and international conflicted were tested through the usage of dataset regarding leaders. However, those taking power or experionces instead of psychological variables that effective on war decisions. In that sense, one should argue the selecting the number of cases is the basic determinant of theorizing. In that sense, we divided our methodological overview into two parts; the first is single and small $n$ studies. The second part is large $n$ case studies.

\subsection{Single and Small N Studies and Leadership Attributes on International Conflict}

The leaders, their perceptions and war have a strong relationship. Perhaps one should assess that the most common form of studies on the individual level of analysis derives from the perceptions of leaders. In that sense, the types of misperceptions, the internal and external dimensions of perception gained importance among the scholars of international relations. (Jervis, 1976, 1988, 2017; Levy, 1983). It must be emphasized here that the research on perception and misperception derives from a comprehensive analysis of historical frequencies. In that sense, the findings of Jervis and Levy are outstanding studies that create a framework for understanding the causes of war at the individual level of IR.

We can define numerous distinct studies on how leaders decide to go to war, however, I argue that the most basic and detailed analyses on intangible variables can be found within the single case studies. In that sense, biographical and personality-based research on war deciders provides important insights on which dynamics substantially affected their behaviors to go to war for specific cases. The 
Methodological Diversity of Research on Leaders and International Conflict: a Review

psychobiography and psychohistory deserve more attention because these researches construct a logic of bridge between early childhood to leadership and leadership to war decision while personality characteristics analysis is the other dimension of the same issue. Both of them give private life information about the observed leaders and their effects upon the war decision. In the context of this study, I selected biographical research, content analytical personality analyses, such as the Leadership Trait Analysis and integrative complexity method among several other methodologies.

\subsubsection{Biographical Studies and Understanding the Causes of War}

Biographies are important single and small $\mathrm{n}$ case study methods to understand specific wars. The question of why wars happen can be extracted from the biographies of war deciders. They give important information on the observed leaders' images, confidences, fears, perceptions, misperceptions towards particular wars. The other biographies for the same wars can be studied systematically and give a chance to compare how leaders are influenced by the environmental factors and how they influenced the inputs and outcomes of the examined war. In that sense, single case biographical research is effective to understand the deepest roots of war such as rivalry among the inner circle, personal relations with the other states' decisionmakers, childhood experiences that are effective on their personalities. As it is known that, different types of biographical (autobiographies, psychobiographies) research can contribute to our understanding. It must be emphasized here that biographies can be regarded as both textual data for political scientists and object of qualitative research. In that sense, particular biographies include the whole military history of a period of a specific country. The biographies on Ataturk can be classified from this point. In addition to this, due to endogenous variables of the leader's effects on international conflict, psychological explanations gain importance thanks to political psychology and provide an opportunity to study the aggressive or defendant behaviors of leaders.

Psychobiography is a field of seeking evidence to understand the leader's behaviors by using their biographies as content. (Houghton, 2009: 85) In that sense, psychobiographers generated various 
frameworks for making comparisons among leaders. By referring Greenstein (Greenstein, 1992), the field mostly focused on communication to the public, organizational capacity, political skill, policy vision, cognitive style, and emotional intelligence that are also important for war and peace studies. According to Winter, profiling political leaders entails considering the private, inferential and public, observable dimensions. They vary according to trans-situational and situation dependent. In this context, this field examines four different elements of personality under the guidance of these variables. These four elements are cognitions, temperaments (traits), motives and social context. (Winter, 2013: 7)

Psychobiography consists of various elements that come from the childhood of the leader to the physical appearance or mental situation. Because of that reason, the creation of data on the political leaders by using psychobiography is hard to do compared with the other descriptive statistical methods. According to Post, this method consists of so many different and maybe private factors such as childhood heroes or models, intelligence, judgment or core beliefs. (Post, 2014)

However, there are some objections to the usefulness of this method. For instance, psychobiographies of leaders may include substantial information to evaluate his/her behavior in a certain context. Nevertheless, most of these biographies are written or documented after the leader left his office and maybe after a long time of his or her pass away. According to Simonton, these biographies might be contaminated by hindsight bias. (Simonton, 2014: 57)

Psychohistory is another method to understand the aggressive behaviors of leaders. Because this method, mostly focused on the mental distress of leaders while they were in power. The method includes some insights from both history and psychology, so named as psychohistory. (Cashman, 2013: 60) It must be emphasized here that most of the psycho-historical analyses can be seen in psychobiography. Because of this reason, one can argue that the findings of psychological research are used today in both historiometric and psychobiographical research.

There is a debate on the utilization of single or small $n$ case studies on theorizing. However, it must be noted here the case studies on single 
personalities can be either theory confirming or hypothesis-generating with the words of Lijphart. (Lijphart, 1971) It means that qualitative case studies on leader's behaviors on international conflict should not be ignored due to their benefits for theory construction.

\subsubsection{Personality Effects on the Outcomes of International Crises and Wars}

Personality profiling of political leaders is a kind of classification work that includes different typologies that can be utilized to analyze their effect on international conflicts. For instance, political psychologists make this classification by using direct psychological data of persons while political scientists mostly focus on how the different behaviors or events are effective on the behaviors of leaders that caused wars. Leadership Trait Analysis (LTA) can be regarded as one of the most common forms of analyzing leaders that use content analytical techniques which presents a model for researchers. As it was mentioned above, the leadership studies pay attention to various personality traits including psychological findings; however, LTA has a different approach to figure out the behaviors of leaders. In other words, LTA mostly concentrated on the effects of a leader's personality and leadership characteristics on the foreign policy behavior through computing them by basic principles which were developed by Hermann. (Hermann, 2005). Primarily, Hermann developed a technique to understand personality characteristics by asking psychologically linked questions to the textual data, such as speeches, interviews or other materials. According to this, (i) how do leaders react to the political constraints, are they resist or adapt to these constraints? (ii) how open are they to the information, are they selective or open to all information that directing their view? (iii) What are the leader's reasons for seeking to come to the office, is this an internal focus of attention or by the relationships formed with salient constituents? These three questions and answers created the basic principles of personality analysis. According to Hermann, these answers to the questions suggest a particular leadership style that can be used in most of the research on war and peace. LTA research based on seven personality traits extracted from political leaders. These traits are belief can control events, need for power, conceptual complexity, self-confidence, task focus, distrust of others and in-group bias. (Hermann, 1980; 2003; Hermann, Milburn, 1977). The utilization of LTA helps us to explain how particular leaders are effective in the 
outcomes of crises, which ended with peace or war. These methods are also used for small $\mathrm{n}$ studies in order to explore how personality characteristics and conflict behavior can be theorized. In that sense, making a comparative leadership analysis is possible in this way. In the literature, the utilization of comparative analysis of political leaders is obviously valid for scientific inquiry. (Kaarbo, Beasley, 1999)

Also, Operational Coding Analysis (OCA) can be regarded as another complementary part of LTA which includes several variables about how the leaders sees the world. It consists of two part; philosophical beliefs and instrumental beliefs. (Post, 2010; Walker et. al, 2003). Understanding te belief system of a political leaders give an opportunity to predict future behaviors. In that sense, together with the LTA research, OCA is another complementary part of political personality profiling.

Besides LTA and OCA research, as a complementary dimension, cognitive complexity gains importance. The measurability of cognitions is an important dimension to understand how international crises evolved into a war. (Conway et. al, 2001; Raphael, 1982; Suedfeld et al., 1977). In that sense, the integrative complexity is another dimension to explain leaders and international conflict. This method is also based upon the quantification of qualitative data, which helps to understand how the change in complexity level of political leaders affects the outcome of crises.

Integrative complexity is a method to explain and understand the cognitive processes of political leaders. These methods were mostly used to bring an explanation of the perceptions of leaders before international crises. According to Suedfeld, who is a psychologist and developed this method, the integrative complexity is a kind of method that extracting data from verbal statements of the political leaders for understanding the complexity level of them towards an issue or attitude. The coding procedure of the method base upon assigning codes from 1 to 7 which are about the degree of complexity. This coding requires considering the different dynamics of the events. This method also helps to show escalation processes during the international crises. (Suedfeld, Bluck, 1988). In this context, this methodology practically applied to war and peace research and could find the best results from the "war crisis effect" (Suedfeld, 2010). 


\section{Methodological Diversity of Research on Leaders and International Conflict: a Review}

As a general overview, the qualitative methods and quantification of qualitative data are important to understand single and small $\mathrm{n}$ research on leadership. In this type of research, hypothesis-generating research is important for theoretical contributions. Besides, the deep roots of particular international conflict on rare events can be understood by the way of those research. The world wars are rare events and studied by systemic, state and dyadic levels. However, the decision-makers which led the world into the war also be studied within this manner. By referring Williamson, the outbreak of World War I was a fusion of long term causes with short-run tactical decisions. Alliances, the role of military bureaucrats and accumulations of different perceptions with personal motivation drag the world into the war in 1914. (Williamson, 1988: 846)

\subsection{Quantification of Leaders' Lives and Theoretical Contributions of Large $\mathbf{N}$ Studies}

Quantification is the most important point of large $\mathrm{n}$ studies for theorizing among conflict scholars. Today we can assess different types of data on leaders, both qualitative and quantitative. These datasets consist of the leader's tenure year and date rather than their psychological or cognitive attitudes. Listing and ranks of leaders can be found within several websites for collecting data. One of them is a website including the political leaders and foreign ministers of states that gives descriptive statistics named rulers.org. This database gives only a piece of brief information on the starting and ending dates of their office, and their birth and death date from 1996 to 2014. The other more detailed database on this field was prepared by worldstatesmen.org including brief explanations of each countries governmental structures, leaders and their birth and death dates. Besides, there some textual databases for psychological research, which are especially on biographies, are found, such as https:// planetrulers.com. This website also presents a classification of leaders such as the head of states, dictators, female leaders, first ladies, etc. However, data generation and collecting on leaders requires more other factors that were defined according to the hypothesis.

Today, the researchers can find numerous data on plenty of subfields within the war and peace research. In addition, the data on the 
domestic variables of countries can be found from various data projects. However, it seems that the smallest number of data on political science was created on leaders. If we adopt it for international conflict, there is too little data on this issue.

Large $\mathrm{N}$ studies on conflict literature consist of different variables such as quantitative or qualitative. The quantitative variables include the categorical variables or the important dates about the leader's office. Qualitative variables derive from textual materials or other biographical research that includes the classification of leaders and their behaviors.

\subsubsection{Empirical Research in International Relations}

Ellis, Horowitz, and Stam introduced one of the most comprehensive datasets in conflict data, and named as Leader Experience and Attributes Descriptions Dataset, LEAD Data. (Horowitz, et. al, 2015; Horowitz, Stam, 2014) If it is compared to the other ones, the LEAD data consists of various variables on leaders which provide an opportunity to study war and peace. In this dataset, the Horowitz et al. created variables to test the hypothesis on how the experiences of the leaders affect the militarized behaviors of countries. Besides, they consider the gender dimension on foreign political behavior along with the education level of leader and decision-making styles. It can be regarded as one of the most important contributions to theorizing leaders and international conflict.

Goemans, Gleditsch, and Chiozza (2009) created a comprehensive dataset on leaders with the name of Archigos. The data were created to question whether there is any relationship between international conflict and leader tenure or not. In other words, the scientists considered here that the international conflict might work in favor of leaders or not. They coded variables by making a typology of losing office. According to Dataset, leaders can lose their office in four different ways. They are shown as (1) a regular manner, (2) an irregular manner (3) through direct removal by another state, (4) natural death (including suicide). Each of them has its classifications and how they lost their office. The result of the data based on the Archigos was published as a book, titled "Leaders and International Conflict." Archigos dataset is one of the most prominent studies on 


\section{Methodological Diversity of Research on Leaders and International Conflict: a Review}

this field and various research on leaders and international conflict was based upon it. In other words, to say that these two data projects can be regarded as pioneer studies of quantitative international relations.

\subsubsection{Another Large N Study: Historiometry}

Methodologically, the quantification is one of the most important points of theorizing behaviors. The empirical studies that abovementioned before highly contributed to the literature. Considering the psychological variables of leaders, how do we quantificate leaders' lives? Political personality analysis requires some indirect methods as a reason for an individual's salient traits. (Winter, 2013: 8) In this context, some research on this field is quantitative along with the qualitative ones. It has some reasons. Apart from the debate on human violence, other perspectives were developed by different disciplines that facilitated to understand the causes of war by focusing on the individual level. One of the most significant attempts to develop a method of analyzing the leaders can be regarded as quantification of leader behaviors, including information about personal characteristics of them. For that reason, notably political psychology, social psychology, and history developed unique methods for the analysis of leaders' behaviors. These attempts also provided a new research discipline named leadership analysis, at the same time contributed political science, and of course IR by including the war and peace studies.

However, making a survey or an investigation with a head of state or other relevant decision-makers is quite impossible. There are two different restrictions for the scientist here. The first one is accessibility to a leader. It is hard to make a direct linkage with a leader. Even if a scientist could find direct communication with a leader, there will be a question that whether the findings are trustable or not and whether it will run for theorizing or not. The second one is the almost plenty of leaders that experienced war has passed away today and possibly the scientist will have no opportunity to find anything other than some texts, speech, diaries, written memories, photos, and videos. (Winter, 2013: 8). 


\section{Öner AKGÜL}

According to Winter, making an empirical approach to the leaders entails the quantification of some traits regarding them. For that reason, the political scientist must behave as a psychologist to figure out the symptoms of leaders at a distance or in other words, some indirect measurement techniques must be applied at such a distance. (Winter, 2013: 8) In this context, the thinkers on the individual level, with a special reference to the leaders, improved some methods to analyze the behavior of leaders that can provide important findings for IR and war studies to theorize the first image. Individuals in politics gained a variety of methods for a long time by taking advantage of various disciplines, such as psychology or the

ty typo typologies. The frameworks created by historiometric methods can be applied to war and peace research. It must also be emphasized here, approximately all the leadership research and data were created on the outstanding leaders. It means that we have plenty of sources and data on the outstanding leaders for research, however, we have limited data to make a comparison on them. The historiometry is a scientific discipline in which nomothetic hypotheses about human behavior are tested by applying quantitative analyses to data concerning historical individuals. (Simonton, 1990: 3) Besides, the historiometry is a way to understand leader behaviors by making classification and by using the data that comes from his/her past experiences, important events that contributed to their personalities, their leadership styles. Methodologically, historiometry is to transforming the process of qualitative information about leaders into quantitative metrics for creating or testing the theories in the field. (Ligon, et. al, 2012: 1014). The method based on the critical life events, psychological background and their effects on outstanding leaders. Accordingly, there are three types of leaders such as charismatic, ideological and pragmatic with two orientations; personalized and socialized. Benefitting from biographies, the historiometric studies presents a large $\mathrm{n}$ data by classifying numerous leaders by their types and orientations. (Ligon, 2008)

In that sense, we can predict that historiometric methods will have a crucial contribution to the explanation of leaders and international 


\section{Methodological Diversity of Research on Leaders and International Conflict: a Review}

conflict. The existing research shows that there are several empirical studies were published which aim to explain the destructiveness of leaders. (Bedell-Avers, 2008; Mumford et al., 2007; O'Connor, et. al. 1995). The findings of these researches are applicable to theorize leaders and international conflict.

\section{CONCLUSION}

In recent years, there has been an increasing interest in the role of individuals, specifically decision-makers, on the causes, processes, and outcomes of international conflicts. The theories such as neoclassical realism, foreign policy analysis (FPA) and political psychology gradually became important because those approaches focused on how leaders behave during particular situations such as before and during international conflict. In that sense, the findings and theories of those fields gained importance within the context of the causes of war and conditions for peace. However, the theory construction on leaders and international conflict remained a debate because it includes both rational and cognitive dimensions. In other words, studying the leaders requires considering both structural variables besides the psychological dynamics. Methodologically, both quantitative and qualitative schools of international relations and political science have attempted to understand or to explain the behaviors of leaders. Explanation of interstate wars was quantitative within the scope of systemic, dyadic or state level in the context of peace science tradition. They have contributed greatly to theory generation on the causes of war. On the other hand, qualitative studies methodologically based on the biographies, speeches or other textual materials of written documents of political leaders. In this field, the research findings are mostly based on the analysis of personality characteristics that were considered as a variable for leaders and effective on international conflict. Both quantitative and qualitative methods have advantages and disadvantages. Questioning how the behaviors of leaders during international conflict and war gradually became a debate among scholars.

The methodological diversity in international conflict scholars is increasing today due to the utilization of various research methodologies. In that sense, due to effects on the psychology on conflict behavior, I argue that the large $n$ qualitative studies may have a greater impact on theorizing. Along with the large $n$ quantitative 


\section{Öner AKGÜL}

studies, the large $\mathrm{n}$ qualitative ones benefit from the single and small $\mathrm{n}$ case studies for data collecting. It means that the large $\mathrm{n}$ datasets on the leader's attributes and personalities will give an impetus to theorize leaders and international conflict. 


\section{Methodological Diversity of Research on Leaders and International Conflict: a Review}

\section{BIBLIOGRAPHY}

Allison, Scott T.; Kramer, M. Roderick; Messick, David M., (Eds.), Conceptions of Leadership: Enduring Ideas and Emerging Insights, New York: Palgrave MacMillan.

Bedell-Avers; Katrina, E., Hunter Samuel, T.; Mumford, Michael D. (2008). "Conditions of Problem-Solving and the Performance of Charismatic, Ideological, and Pragmatic Leaders: A Comparative Experimental Study". The Leadership Quarterly, 19(1), 89-106.

Blainey, Geoffrey (1988). The Causes of War. Australia: Simon and Schuster.

Brams, Steven J. (2002). “Game Theory in Practice: Problems and Prospects in Applying it to International Relations", Brecher, Michael ; Harvey, Frank P. (Eds.), Millennial Reflections on International Studies, Ann-Arbor: University of Michigan Press, 392-404.

Bremer, Stuart A. (1992). “Dangerous Dyads: Conditions Affecting the Likelihood of Interstate War, 1816-1965". Journal of Conflict Resolution, 36(2), 309-341.

Cashman, Greg (2013). What Causes War?: An Introduction to Theories of International Conflict. Maryland: Rowman \& Littlefield.

Chiozza, Giacomo; Goemans, Hein E. (2011). Leaders and International Conflict. New York: Cambridge University Press.

Chiozza, Giacomo; Goemans, Hein E. (2004). "International Conflict and the Tenure of Leaders: Is War Still Ex Post Inefficient?". American Journal of Political Science, 48(3), 604-619.

Chiozza, Giacomo; Goemans, Hein E. (2003). "Peace Through Insecurity: Tenure and International Conflict". The Journal of Conflict Resolution, 47(4), 443-467.

Conway III, L. Gideon; Suedfeld, Peter; Tetlock, Philip E. (2001). “Integrative Complexity and Political Decisions that Lead to War or Peace", Christie, Daniel J., Wagner, Richard V.; Winter, Deborah Du Nann (Eds.), Peace, Conflict, and Violence: Peace Psychology for the 21st Century, New Jersey: Prentice-Hall, 66-75.

De Mesquita, Bruce Bueno (2002). "Accomplishments and Limitations of a Game-Theoretic Approach to International Relations", Brecher, Michael ; Harvey, Frank P. (Eds.), Millennial Reflections on International Studies, AnnArbor: University of Michigan Press, 374-391.

De Mesquita, Bruce Bueno. (2006). “Game Theory, Political Economy, and the Evolving Study of War And Peace". American Political Science Review, 100(4), 637-642. 
Debs, Alexandre; Goemans, Hein E. (2010). "Regime Type, the Fate of Leaders, and War". American Political Science Review, 104(3), 430-445.

Falk, Avner (1985). "Aspects of Political Psychobiography". Political Psychology, 6(4), 605-619.

Fordham, Benjamin O. (2005). "Strategic Conflict Avoidance and the Diversionary Use of Force". Journal of Politics, 67(1), 132-153.

Goemans, Hein E.; Gleditsch, Kristian S.; Chiozza, Giacomo (2009). "Introducing Archigos: A Dataset of Political Leaders". Journal of Peace Research, 46(2), 269-283.

Greenstein, Fred I. (1992). "Can Personality and Politics Be Studied Systematically?". Political Psychology, 105-128.

Guttieri, Karen; Wallace, Michael D; Suedfeld, Peter (1995). "The Integrative Complexity of American Decision-Makers in the Cuban Missile Crisis". Journal of Conflict Resolution, 39(4), 595-621.

Hermann, Margaret G. (1980). “Explaining Foreign Policy Behavior Using the Personal Characteristics of Political Leaders". International Studies Quarterly, 24(1), 7-46.

Hermann, Margaret G. (2003). "Assessing Leadership Style Trait Analysis", Post, Jerrold M. (Ed.), The Psychological Assessment of Political Leaders, AnnArbor: University of Michigan Press, 178-212.

Hermann, Margaret G.; Milburn, Thomas W. (1977). A Psychological Examination Of Political Leaders. New York: Free Press.

Horowitz, Michael C.; McDermott, Rose; Stam, Allan C. (2005). “Leader Age, Regime Type, and Violent International Relations". Journal of Conflict Resolution, 49(5), 661-685.

Horowitz, Michael C.; Ellis, Cali M.; Stam, Allan C. (2015). leaders_datapaper_replication_final_9_10_15.tab. In Replication Data for: Introducing the LEAD Data Set (V1 ed.): Harvard Dataverse.

Horowitz, Michael C.; Fuhrmann, M. (2018). “Studying Leaders and Military Conflict: Conceptual Framework and Research Agenda". Journal of Conflict Resolution, 62(10), 2072-2086.

Horowitz, Michael C.; Stam, A. C. (2014). “How Prior Military Experience Influences the Future Militarized Behavior of Leaders". International Organization, 68(3), 527-559.

Horowitz, Michael C.; Ellis, Cali M.; Stam, Allan C. (2015). Why Leaders Fight: New York: Cambridge University Press.

Houghton, David P. (2009). Political Psychology: Situations, Individuals, and Cases. NY- London: Routledge. 


\section{Methodological Diversity of Research on Leaders and International Conflict: a Review}

Jervis, Robert (1976). Perception and Misperception in International Politics. Princeton: Princeton University Press.

Jervis, Robert (1988). “War and Misperception". The Journal of Interdisciplinary History, 18(4), 675-700.

Jervis, Robert (1993). "Arms-Control, Stability, and Causes Of War". Political Science Quarterly, 108(2), 239-253.

Jervis, Robert (2017). How Statesmen Think: The Psychology of International Politics. Princeton-Oxford: Princeton University Press.

Kaarbo, Juliet; Beasley, Ryan K. (1999). “A Practical Guide To The Comparative Case Study Method In Political Psychology". Political Psychology, 20(2), 369-391.

Levy, Jack S. (1987). "Declining Power and the Preventive Motivation for War". World Politics, 40(1), 82-107.

Levy, Jack S. (1992a). "An Introduction to Prospect Theory". Political Psychology, 171-186.

Levy, Jack S. (1992b). "Prospect Theory and International Relations: Theoretical Applications and Analytical Problems". Political Psychology, 283310.

Levy, Jack S. (1996). "Loss Aversion, Framing, and Bargaining: The Implications of Prospect Theory for International Conflict". International Political Science Review, 17(2), 179-195.

Levy, Jack S. (1997). "Prospect Theory, Rational Choice, and International Relations". International Studies Quarterly, 41(1), 87-112.

Levy, Jack S. (1983). “Misperception and The Causes Of War: Theoretical Linkages and Analytical Problems". World Politics, 36(1), 76-99.

Ligon, Gina S.; Harris, Daniel J.; Hunter, Samuel T. (2012). “Quantifying Leader Lives: What Historiometric Approaches Can Tell Us". The Leadership Quarterly, 23(6), 1104-1133.

Ligon, Gina S.; Hunter, Samuel T; Mumford, Michael D. (2008). "Development Of Outstanding Leadership: A Life Narrative Approach". Leadership Quarterly, 19(3), 312-334.

Lijphart, Arend (1971). "Comparative Politics and The Comparative Method". American Political Science Review, 65(3), 682-693.

Lobell, Steven E.; Ripsman, Norrin M.; Taliaferro, Jeffrey W. (2009). Neoclassical Realism, the State, and Foreign Policy. New York: Cambridge University Press.

McDermott, Rose (2001). Risk-Taking In International Politics: Prospect Theory In American Foreign Policy. Ann-Arbor: University of Michigan Press. 
McDermott, Rose (2004). "Prospect Theory In Political Science: Gains and Losses From The First Decade". Political Psychology, 25(2), 289-312.

Mead, Margaret (2000). "Warfare is Only an Invention-Not a Biological Necessity" (Originally Published in Asia, XL, 1940: 402-5), Barash, David (Ed.) Approaches to Peace: A Reader in Peace Studies, New York: Oxford University Press, 19-22.

Mercer, Jonathan (2005). "Prospect Theory and Political Science". Annual Review of Political Science, 8, 1-21.

Miller, Ross A. (1999). "Regime Type, Strategic Interaction, and the Diversionary Use of Force". Journal of Conflict Resolution, 43(3), 388-402.

54
Mumford, Michael D.; Espejo, Jazmine; Hunter, Samuel T.; Bedell-Avers, Katrina E.; Eubanks, Dawn. L.; Connelly, Shane. (2007). "The Sources of Leader Violence: A Comparison of Ideological and Non-Ideological Leaders". The Leadership Quarterly, 18(3), 217-235.

O'Connor, Jennifer; Mumford, Michael D.; Clifton, Timothy C.; Gessner, Theodore L.; Connelly, M. Shane. (1995). "Charismatic Leaders and Destructiveness: An Historiometric Study". The Leadership Quarterly, 6(4), 529555.

Parry, Ken.; Mumford, Michael D.; Bower, Ian; Watts, Logan L. (2014). "Qualitative and Historiometric Methods in Leadership Research: A Review of the First 25 Years of the Leadership Quarterly". The Leadership Quarterly, 25(1), 132-151.

Post, Jerrold M. (2014). "Personality Profiling Analysis", Rhodes, R. A. W.; Hart, Paul 't (Eds.), Oxford Handbook of Political Leadership, Oxford: Oxford University Press.

Post, Jerrold M. (2010). The Psychological Assessment of Political Leaders: With Profiles of Saddam Hussein and Bill Clinton. Ann-Arbor: University of Michigan Press.

Raphael, Theodore D. (1982). “Integrative Complexity Theory and Forecasting International Crises: Berlin 1946-1962". Journal of Conflict Resolution, 26(3), 423450 .

Rose, Gideon. (1998). "Neoclassical Realism and Theories Of Foreign Policy". World Politics, 51(1), 144-172.

Senese, Paul D.; Vasquez, John A. (2005). “Assessing the Steps to War". British Journal of Political Science, 35(4), 607-633.

Shafir, Eldar (1992). "Prospect Theory and Political Analysis: A Psychological Perspective". Political Psychology, 311-322.

Simonton, Dan Keith (1990). Psychology, Science, and History: An Introduction To Historiometry. New Haven: Yale University Press. 


\section{Methodological Diversity of Research on Leaders and International Conflict: a Review}

Simonton, Dan Keith (2014). "The Personal Characteristics of Political Leaders: Quantitative Multiple-Case Assessment". Goethals George R.;

Singer, J. D. (1961). "The Level-of-Analysis Problem in International Relations". World Politics, 14(1), 77-92.

Siverson, Randolph M.; Starr, Harvey (1990). “Opportunity, Willingness, and the Diffusion of War". American Political Science Review, 84(1), 47-67.

Siverson, Randolph M.; Starr, Harvey (1991). The Diffusion of War: A Study of Opportunity and Willingness. Ann-Arbor: University of Michigan Press.

Starr, Harvey (1978). “' 'Opportunity' and 'Willingness' as Ordering Concepts in the Study of War". International Interactions, 4(4), 363-387.

Suedfeld, Peter (2010). "The Cognitive Processing of Politics and Politicians: Archival Studies of Conceptual and Integrative Complexity". Journal of Personality, 78(6), 1669-1702.

Suedfeld, Peter; Bluck, Susan (1988). "Changes in Integrative Complexity Prior to Surprise Attacks". Journal of Conflict Resolution, 32(4), 626-635.

Suedfeld, Peter; Jhangiani, Rajiv (2009). "Cognitive Management in an Enduring International Rivalry: The Case of India and Pakistan". Political Psychology, 30(6), 937-951.

Suedfeld, Peter; Tetlock, Philip (1977). “Integrative Complexity of Communications in International Crises". Journal of Conflict Resolution, 21(1), 169-184.

Suedfeld, Peter; Tetlock, Philip E; Ramirez, Carmenza (1977). “War, Peace, and Integrative Complexity: Un Speeches on the Middle East Problem, 19471976." Journal of Conflict Resolution, 21(3), 427-442.

Tir, Jaroslav (2010). “Territorial Diversion: Diversionary Theory of War and Territorial Conflict". Journal of Politics, 72(2), 413-425.

Vasquez, John A. (1998). The Power of Power Politics: From Classical Realism to Neotraditionalism. New York: Cambridge University Press.

Vasquez, John A. (2009). The War Puzzle. New York: Cambridge University Press.

Walker, Stephen G.; Watson, George L. (1994). "Integrative Complexity and British Decisions during the Munich and Polish Crises". Journal of Conflict Resolution, 38(1), 3-23.

Walker, Stephen G.; Schafer, Mark; Young, Michael D. (2003). "Profiling the Operational Codes of Political Leaders", Post, Jerrold M. (Ed.), The Psychological Assessment of Political Leaders: With Profiles of Saddam Hussein and Bill Clinton, Ann-Arbor: University of Michigan Press, 215-245. 


\section{Öner AKGÜL}

Waltz, Kenneth N. (2001). Man, the State and War. New York: Columbia University Press.

Williamson, Samuel R. (1988). "The Origins of World War I". The Journal of Interdisciplinary History, 18(4), 795-818.

Winter, David G. (2007). "The Role of Motivation, Responsibility, and Integrative Complexity in Crisis Escalation: Comparative Studies of War and Peace Crises". Journal of Personality and Social Psychology, 92(5), 920-937.

Winter, David G. (2013). "Personality Profiles of Political Elites". Huddy, Leonie; Sears, Devid O.; Levy, Jack S. (Eds.), The Oxford Handbook of Political Psychology, New York: Oxford University Press, 423-458

56 Winter, David G.; Hermann, Margaret G.; Weintraub, Walter; Walker, Stephen G. (1991). "The Personalities of Bush and Gorbachev Measured at a Distance: Procedures, Portraits, and Policy". Political Psychology, 215-245. 


\section{Methodological Diversity of Research on Leaders and International Conflict: a Review}

\section{ÖZET}

Uluslararası ilişkiler literatüründe gerek klasik gerek günümüzde birçok yazar, savaşın nedenleri ve barışın koşullarına ilişkin varsayımlar ileri sürdüler. Hobbes'tan Rousseau'ya, Waltz'dan Deutsch'a kadar neredeyse her yazar savaşın nedenlerine ilişkin sistemli açılamalar getirdiler. Ancak bunların çok büyük bir çoğunluğunun temel dayanağı insan doğası olup, savaşa karar veren birimlerin teknik manada incelenmesini içermemiştir. Dolayısıyla, savaşın nedenlerinden krizin doğasına kadar realist perspektifin üzerinde durduğu her aşamada bir 'karar' karşımıza çıktığından, özel ve teknik olarak liderlerin sistematik analizi fazlasıyla Soğuk Savaş dönemine kalmıştır. Bu dönemde gerek uluslararası ilişkiler teorisyenleri gerekse, psikologlar liderlerin saldırgan davranışlarından, çatışma esnasındaki rasyonel-irrasyonel davranışlara kadar birçok konuda nitelikli yayınlar ortaya koymuşlardır. Dolayısıyla her ekolün kendi metodolojisiyle liderlerin savaş ve kriz davranışını analiz etmesi durumu ortaya çıkmıştır. Davranışsalcı akımın uluslararası ilişkilerde bir meydan okuma olarak belirmesi, ardından post-modernizmin önem kazanmasıyla birlikte, lider analizlerinin de bundan etkilendiğini ileri sürmek yanlış olmayacaktır. Tüm bu bilgiler ışı̆̆ında, farklı teorik altyapıların, farklı metodolojiler kullandığı ve bu metodolojilerin de lider çalışmalarına ciddi katkılar sağladığı ifade edilebilir. Dolayısıyla bu çalışma, liderler ve uluslararası çatışma davranışı arasındaki korelasyonu, farklı boyutlarıyla ancak aynı hedefle arayan araştırmacılar açısından bir rehber oluşturmak amacıyla hazırlanmıştır.

Uluslararası ilişkiler alan literatüründe neo-realizmin yükselişi ile birlikte, göz ardı edilen liderler ve davranışları, özellikle Soğuk Savaş'tan sonra önem kazanmaya başlamıştır. Neo-klasiklerin varlığı, dış politika analizi'nin önemli bir alan olarak belirmesi, politik psikolojinin popüler hale gelmesi ile birlikte, alanda birçok yazar az ya da çok liderlerin önemini teyit etmektedir. Bu çalışmada önemsenen husus ise, bu teorileri açıklamaktan ziyade, liderlerin savaş davranışını açıklama çabasındaki yazarların hangi farklı yöntemleri kullandığıdır. Nitekim teorileştirme sürecinin kökeninde metodoloji yatmaktadır ve nicel/nitel her yöntem teorik tutarlılığı içinde kullanıldığında anlamını bulmaktadır. Bu bağlamda liderler ve uluslararası çatışma davranışının analizinde iki husus önem kazanmaktadır. Özellikle nitel çalışmaların lider davranışlarını spesifik olaylar çerçevesinde anlama, nicel çalışmaların ise bu davranışlarını teorik açıdan açılama çabasındadır. Metodolojik rekabet bir kenara bırakılırsa, her birinin akademiye katkıları önemlidir.

Bu çalışma kapsamında nitel ve nicel, tek vaka ve çok vaka incelemelerine dayalı metodolojik tercihler tartışılmaktadır. Bu açıdan nitel anlamda biyografik çalışmaların (psikobiyografi, otobiyografi ya da psikotarih yöntemleri), tek vaka ya da birkaç mukayeseli vaka incelemelerinde derin bir 


\section{Öner AKGÜL}

bilgi sunduğu ifade edilebilir. Başka bir ifadeyle, sistemik ya da tarihsel süreçlerin dışında, bu biyografilerden liderlerin algılama süreçleri, psikolojik eğilimlerinin kararlarına etkileri hatta çocukluk travmalarının bile bazı kararlarında ne kadar etkili olabileceği değerlendirilmektedir. Öte yandan kişilik karakter tahlili (LTA), Margaret Hermann tarafından geliştirilen bir tahlil metodu olup, içerik analizi tekniği ile liderlerin konuşma metinleri üzerinden onların karakterini analiz ederek bunun dış politika çıtılarına yansımalarını ortaya çıkarmaktadır. Bu açıdan günümüzde en fazla kullanılan yöntemlerden birisidir. Liderlerin karmaşık durumlarda bilgiyi nasıl işlediklerini göstererek bir indeks değeri çıkaran bütünleşik karmaşıklık seviyesi ise bir diğer metod olup, Hermann'ın metodolojisini tamamlayıc1 niteliktedir. Bunların dışında operasyonel kodlama analizi gibi liderin dış dünyayı nasıl tanımladığı ve nasıl reaksiyon geliştirdiğine ilişkin metodolojilerde nitel metodlar arasında yerini almaktadır. Bunların tamamı, nitel verinin nicelleştirilerek öngörü sağlayan mekanizmalar yaratımını sağlamaktadır.

Ancak liderler ve uluslararası çatışma davranışını teorik olarak açıklamak, çok fazla liderin (geniş örneklem) standart bir kalıp içinde değerlendirilmesini gerektirmektedir. Bu açıdan, nicel metodları kullanan ampirik uluslararası ilişkiler teorisi, 1816 'dan günümüze kadar gelen liderlerin bilgilerini içeren verisetleri oluşturarak teorik önermeleri sınamaya başlamışlardır. Günümüzde LEAD ve Archigos veri setlerinin, nicel analizler yapan yazarlar açısından bir başlangıç noktası olduğu görülmektedir. Bu açıdan alanda ciddi rağbet görmüş ve bugün liderlerin davranışlarına ilişkin hipotez geliştiren yazarlar büyük ölçüde bu verisetlerini kullanmaktadır. Bu verisetlerinde liderlere ilişkin birçok bilgi bulunmaktadır. Liderin göreve başlama ve bitiş tarihleri, görevi bittikten sonraki durumu, ölüm şekli (normal, intihar, suikast), iktidara geliş biçimi, iktidardan ayrılma biçimi, askeri deneyiminin olup olmadığı, isyancı birliklerinin bir parçası olup olmadığı ve bunun gibi birçok değişkeni içermektedir. Bu açıdan nicel analize ve dolayısıyla teoriye ciddi katkılarda bulunmuştur.

Nicel ve nitel alan birlikte değerlendirildiğinde, her ikisinin de avantajları ve dezavantajları olduğu açıktır. Nicel metodlar teori geliştirebilir ancak detayı kaçırırlar. Yukarıda bahsedilen verisetlerinde, liderlerin psikolojik durumlarına ilişkin bilgiler yoktur. Başka bir ifadeyle, liderleri psikolojik özellikleri ve karakterlerine göre sınıflandırdığımız, teorileşmeye hizmet edebilecek bir geniş örneklemli veriseti bulunmamaktadır. Oysaki bazı savaşları anlamak bu detaylardan geçebilir. Öte yandan nitel metodlar ise derinlemesine analiz sağlayabilirken, çok sınırlı sayıda lideri birlikte inceleyebilmektedir. Dolayısıyla bir teori oluşturma sürecine katkıları, nicel metodlarla ilerleyen çalışmalarla mukayese edildiğinde düşüktür. Bu çalışma kapsamında benim iddiam, historiometry alanının, liderlerin doğumlarında ölümlerine kadar her aşamasının, biyografiler ve psikobiyografilerden gelen 


\section{Methodological Diversity of Research on Leaders and International Conflict: a Review}

verilerle nicelleştirilerek psikolojinin verilerine bağlı kalınarak geniş örneklemli veri setleri hazırlamasının, alana oldukça faydası olacağı yönündedir. Bu açıdan historiometrik bulguların kısa ve orta vadede birçok uluslararası ilişkiler çalışmasında kullanılacağı iddia edilmektedir. 
